\title{
Exogenous political institutions? Constitutional choice in post-independence \\ Francophone sub-Saharan Africa
}

\author{
Robert Elgie
}

\section{School of Law and Government, Dublin City University Dublin 9, Ireland}

e-mail: robert.elgie@dcu.ie

\begin{abstract}
The study of the effects of institutions suffers from a potential endogeneity problem. This article proposes a strategy for addressing this problem by estimating the motivations for institutional choice directly. It identifies the motivations behind the wording of post-independence constitutions in Francophone sub-Saharan Africa. We find that constitutional wording in these countries has been motivated by the strength of ties with France. However, contrary to standard narratives, domestic political preferences have also been influential. By estimating the motivations for institutional choice directly, we are better placed to draw conclusions about the independent effect of institutions in this region.
\end{abstract}

\section{Keywords}

Institutions, constitutional choice, endogeneity, France, neo-colonialism, subSaharan Africa 
The study of the effects of institutions is long-standing. By contrast, the study of institutional choice is much less developed. This is puzzling. The study of institutional choice is theoretically prior to the study of the effects of institutions. This is because the study of the effects of institutions suffers from a potential endogeneity problem. For example, we want to know whether presidentialism creates a personalisation of the political system that is dangerous for young democracies. However, if a particular person was sufficiently dominant in the constitution-making process to insist on the choice of presidentialism and then occupied the presidential office after the constitution has been implemented, we would have to be careful to ascribe any independent explanatory effect to presidentialism if the country then suffered from the problems of personal rule. To identify the independent effects of institutions, we need to understand the circumstances under which they were chosen in the first place.

In this article, we propose a two-stage strategy for addressing the problem of endogenous institutional choice. The first stage estimates the motivations for institutional choice directly. The second stage examines the causal effects of institutions in the standard way. In this article, we focus on the first stage of this strategy. By including variables that capture both endogenous and exogenous motivations, we identify the endogeneity problem directly. If we find that only exogenous variables are significant in the estimation, then we are well placed to examine the causal effects of institutions in a second-stage study. If we find that only endogenous variables are significant, then we would have to doubt the extent to which institutions exterted an independent effect. If we find that both types of variables are significant, then we can devise a focused research strategy to address the endogeneity problem in the second stage of the study. 
To illustrate this strategy, we examine the wording of post-independence constitutions in Francophone sub-Saharan Africa. When examining this region, there is a standard narrative that France has generally maintained a neo-colonial relationship with its former colonies. Moreover, there is an equivalent narrative that emphasises the extent to which countries there have often adopted carboncopies of the 1958 French constitution. Thus, we would expect to find that the wording of these countries' constitutions has been largely the result of exogenous political preferences. When we estimate the motivations for constitutional choice directly, what is the evidence to support such an expectation? To answer this question, we rely on a unique data set that codes almost every constitutional moment in 15 sub-Saharan Francophone African countries for a 50-year period from the point of independence in 1960 to 2010. We find that constitutional wording in these countries has been motivated in part by exogenous French influence. However, contrary to standard narratives, domestic political preferences have also been influential. These results suggest that institutions may have had an independent causal effect in this region. At the same time, they also demonstrate that institutions were chosen at least partly endogenously. By identifying specific endogenous motivations, we are well placed to devise a focused research strategy that addresses the endogeneity problem in the second stage of a research strategy.

\section{The endogenous selection of institutions}

Students of political institutions are faced with a dilemma. We assume that institutions shape the preferences of political actors. On the basis of this 
assumption, we wish to identify how actors respond to certain institutional arrangements. If we can do so, we can make policy-relevant recommendations as to which institutions are likely to generate better governance. At the same time, though, we know that institutions are often chosen endogenously. That is to say, the individuals or forces who operate under a given institutional system are often the ones who chose that system. If individuals choose institutions that reflect their pre-existing preferences, when they operate under those same institutions their behaviour is not being shaped by them. Instead, institutions are inducing behaviour that is consistent with their pre-existing preferences. When institutions are endogenously selected, the direction of causation is reversed. Institutions are not so much the cause of particular preferences, they are the consequence of those preferences. In this case, "institutions have no autonomous role to play. Conditions shape institutions and institutions only transmit the causal effects of these conditions (Przeworski, 2004, p. 527).

The problem of the endogenous selection of institutions is well known (Aghion et al., 2004; Engerman and Solokoff, 2008; Shvetsova, 2003; Ticchi and Vindigni, 2010) and there are a number of strategies for addressing it. The most common statistical procedure is the use of an instrumental variable in a twostage least squares regression estimation. There are difficulties associated with the use of instrumental variables, notably the problem of weak and invalid instruments (Murray, 2006, p. 112). There is also the problem that the number of instrumental variables in an equation needs to be as great as the number of potentially endogenous variables, yet strong and valid instruments are often difficult to identify. All the same, if instrumental variables are operationalised with care, they can be "extraordinarily useful both as an estimation approach 
and as a framework for research design" (Sovey and Greene, 2011, p. 199). Another strategy is the identification of natural experiments. Again, there are limitations to the use of natural experiments. For example, they may suffer from the problems of noncompliance, when "places assigned to the treatment group go untreated, while places assigned to the control group receive treatment" (Gerber and Greene, 2008, p. 367), and attrition, when "outcomes are unobserved for certain observations" (ibid., p. 372). Nonetheless, like the use of instrumental variables, the use of natural experiments to identify the direction of causality is an essential part of the methodological toolkit.

In this article, we propose a complementary strategy for addressing the problem of endogenous institutional choice. We propose a two-stage strategy. The first stage estimates the motivations for institutional choice directly. The second stage examines the causal effects of institutions in the standard way. In this article, we focus on the first stage of this strategy. To estimate the motivations for institutional choice directly, we include variables that capture both endogenous and exogenous preferences. This strategy allows us to draw explicit conclusions about the circumstances under which institutions have been adopted. On the basis of such conclusions, we can proceed to a standard analysis of the causal effect of institutions, but from a robust platform. For example, if we include variables that capture both endogenous and exogenous motivations in an equation and we find that only the exogenous variables are significant predictors of institutional choice, then we can reasonably assume that institutional choice was the result of external influence. Such a result would be the equivalent of a first-stage robustness test, indicating that there were good grounds to proceed to a standard test of the causal impact of institutions on political outcomes. By 
contrast, if we include both types of variables in an equation and find that only the endogenous variables are significant predictors of institutional choice, then we would have to be extremely careful when drawing any conclusions about the independent effect of institutions in any subsequent study of the topic under consideration. Indeed, such a result might be employed as the equivalent of a first-stage robustness test for a scholar who wished to propose a society-centred explanation of political outcomes, providing grounds to suggest that the independent impact of institutions of political outcomes should be discounted.

While it is feasible that institutions could be imposed on a country by external actors, it is much more likely that even if there is a degree of imposition domestic actors will also have at least some influence over the process of institutional choice. Equally, even when domestic actors appear to have full control over the process of institutional choice, their preferences are likely to be shaped to a greater or lesser degree by external interests and ideas. Therefore, while institutional choice could be either purely exogenous or endogenous, in all likelihood it will be a mix of both. If we estimate the motivations for institutional choice directly, we have a strategy for addressing this mix. For example, if an equation included both endogenous and exogenous determinants of institutional choice and we found that certain endogenous variables were significant, we could then choose a case selection strategy that controlled for those variables in any subsequent estimation of institutional effects, we could identify specific instruments that could be applied to the particular endogenous variable, or we could adopt a process-tracing approach (Collier et al., 2004) that would allow us to identify the specific impact of the relevant endogenous variables at each stage of institutional choice. When institutional choice is the result of a mix of domestic 
and external preferences, the advantage of estimating the motivations of institutional choice directly is that we can identify the specific variables that are endogenous to a particular study and then devise a research strategy to account for them, allowing us to proceed to the identification of the causal effects of institutions more explicitly.

Overall, we do not wish to argue that this two-stage approach should replace strategies that use instrumental variables or natural experiments. We merely suggest that estimating the motivations for institutional choice directly can provide us with a complementary strategy for addressing the problem of institutional endogeneity. As the first stage of a given study, such a strategy can confirm whether or not institutions are likely to have had an independent effect on political outcomes and also which endogenous variables need to be taken into account. In the next section, we provide an example that demonstrates how the endogenous and exogenous determinants of institutional choice can be estimated directly.

\section{Institutional choice in post-independence francophone sub-Saharan Africa}

To what extent is the motivation for institutional choice endogenous or exogenous? To answer this question, this article focuses on 15 Francophone subSaharan Africa countries from the point of independence to 2010. They comprise the four countries of the former federation of French Equatorial Africa (Central African Republic, Chad, Republic of Congo, and Gabon), the eight countries of the former federation of French West Africa (Benin, Burkina Faso, Côte d'Ivoire, 
Guinea, Mali, Mauritania, Niger, and Senegal), the two former French Mandate countries (Cameroon and Togo), and the former French colony of Madagascar.

There are two reasons for this case selection. The first is that these countries have many standard attributes in common. For example, by definition, they have a heritage of French colonial rule, including the organisation of the colonial economy, bureaucracy, representative institutions and so forth. In addition, they are all relatively poor countries economically and they are all also highly divided along ethnic lines (Alesina et al. 2003). Also, these countries all achieved independence from France within a very short space of time. Guinea was the first to do so, being the only country to reject membership of the French Community in September 1958. The remaining 14 countries became independent at some point in 1960, eight of them in August of that year, by which time the French Community was effectively dissolved. Therefore, by examining this set of countries and, for example, by excluding any consideration of the former French colonies of the Comoros Islands and Djibouti, which became independent only in 1975 and 1977 respectively, we are controlling for any systematic effect that may result from the date of independence.

The second reason is that there is a strong foundation for the claim that institutional choice in this region has been affected by exogenous factors. Specifically, France has maintained a very close relationship with countries in this region since independence. The standard interpretation of this relationship presents it as neo-colonial (Goncharov, 1963; Suret-Canale, 1974; Golan, 1981, p. 10; Chafer, 2002a, p. 345; Cumming, 2000, p. 360; Gregory, 2000, p. 435; Charbonneau, 2008, p. 280; Majumdar and Chafer, 2010, p. 204; Verschave, 1998, 2000). Even if the term 'neo-colonial' is not employed, the relationship between 
France and its former colonies in sub-Saharan Francophone Africa is often considered to be somehow exceptional:

This is reflected in a number of French expressions used to describe Francophone African countries, such as domaine réservé (private matter), chasse-gardée (exclusive hunting ground) or pré-carré (natural preserve), which prescribe the backyard as being 'off limits' to other great powers (Renou, 2002, p. 6).

In short, most observers conclude that French influence over its former colonies has remained very great since independence. If they are correct, then if we can estimate the motivations for institutional choice directly we should find that exogenous French factors are associated with institutional outcomes in these countries.

The foundations of French influence in sub-Saharan Francophone Africa are commonly accepted. Four factors are routinely identified. The first is economic. Here, France was in a position to obtain scarce natural resources from many of its former colonies and establish a market for its own exports. There was considerable French investment in the economies of its former colonies, corresponding to a form of "rentier-capitalism" (Hugon, 2005, p. 43). These countries had, in practice, a common currency, the CFA franc, that was pegged to the French franc and now the euro. The result, Renou (2002, p. 11) argues, was that it enabled "France to control Francophone African countries' money supply, their monetary and financial regulations, their banking activities, their credit allocation and ultimately, their budgetary and economic policies". These countries were also major recipients of French overseas aid. Formally, this aid was not 'tied'. In reality, though, recipient countries were encouraged to buy 
French goods and/or to reward French companies with the contracts for infrastructure and investment projects. The second factor is military (Luckham, 1982). France signed defence and security agreements with many of its former colonies. In certain countries it had military bases. In these countries and others, France was willing to intervene to prevent coups or to support them if they were felt to be in the best interests of France (Ayissi, 1999). The level of involvement was sporadic but often decisive, with France coming to be known as the gendarme (policeman) of Africa. The third factor is cultural. Here, Ager (2005, p. 58) argues, "France's aim was to maintain privileged relations with former colonies, amongst other means by ensuring that the French language was used, that education was provided in and through French, and that cultural activities through the medium of French were available". Support for the French language is the most visible sign of cultural links. However, Joseph (1976, p. 10) emphasised the importance of France's role in education too: "Entire university and secondary school systems were supplied, from the physical plant to details of curricula, examination systems, teaching materials and personnel regulation". He concludes "French educational models have become more entrenched during the expansion of the African educational systems since independence" (ibid.). The final factor is personal. French influence was underpinned by a network of personal contacts. These went to the highest level, with presidential involvement a constant factor in policy making in this region. In addition, it involved the influence of particular individuals who were close to the president, notably Jacques Foccart under President de Gaulle and President Pompidou, and Guy Penne and then Jean-Christophe Mitterrand under President Mitterrand. These people enjoyed privileged access to decision-makers in former colonies, but there 
was also a wider network of officials, experts and advisers who were able to transmit France's interests and values in the region.

While across the set of writers there is a difference of emphasis as to the nature of France's relationship with its former colonies in sub-Saharan Francophone Africa, there is general agreement that France has been, and remains, a highly influential actor in the region. Directly or indirectly French preferences are believed to have shaped a wide range of policies and, consequently, the post-independence histories of the countries in this region. To what extent have post-independence Francophone sub-Saharan African institutions been the result of domestic or external preferences? The standard wisdom suggests that they should have been the result of exogenous French preferences. To what extent is this the case?

\section{Constitutional choice in post-independence Francophone sub-Saharan Africa}

To identify the extent to which institutions have been chosen endogenously or exogenously in this region, we focus on the process of constitutional choice. There is a strong basis for this choice. The standard interpretation of constitutional choice in post-independence Francophone sub-Saharan Africa is well documented. According to this interpretation, at the time of independence the countries in this study adopted "carbon copy constitutions" (Davies, 1963, p. 328) that closely resembled the 1958 French Constitution. This period was marked by a process of constitutional "mimetism" (Conac, 1979, p. 8)," whereby the French metropolitan model was transposed onto the African context. For some writers, these constitutions were "a set of alien rules" that had usually been 
written in Europe and were handed down from on high (Mbaku, 2003, p. 112).

For others, these constitutions were "imposed" but for historical and cultural reasons, namely the historically dominant position of France and the political culture and experience of the African leaders (Glélé, 1980, p. 33).

Following this period of seemingly explicit constitutional borrowing, the standard interpretation indicates that African countries then started to adopt a more indigenous constitutional model. For some observers, this process began in the early 1960s when countries started to adopt personalised presidential rule and one-party states (Le Vine, 1997, p. 187). For others, the process began in the mid-1960s and particularly the 1970s when countries adopted marxist-style constitutions. For example, Conac (1979, p. 16) talks of the "Africanisation" of constitutions during this period, while Reyntjens (1991, p. 51) identifies "25 years of innovations and experiments". Perhaps unsurprisingly, writers more or less explicitly identify domestic political preferences as being responsible for changing constitutional choices during this time. So, Glélé (1980, p. 32) argues that there was an "acculturation" of the French model, with countries adapting it in ways that "responded to their own socio-political and economic realities". For his part, Le Vine (1997, p. 188) provides a host of domestic reasons why the first post-colonial constitutions in this region were "so soon left behind, abandoned, or abrogated".

This situation changed in the early 1990s. At a time when there was a wave of democratisation or at least political liberalisation across the world generally, most Francophone sub-Saharan Africa adopted new constitutions or extensively revised existing ones. For Reyntjens, these countries "again sought their inspiration in what they perceive[d] as a reliable and unsuspected 
democratic model: that of France" (1991, p. 51). Cabanis and Martin (2005, p. 357) speak of a process of "isomorphism" whereby the constitutions of the 1990s "are closer than ever to the model belonging to the former colonial power". A doyen of constitutional studies in this region, Jean du Bois de Gaudusson (2009, p. 47), encapsulates the standard wisdom in the following way: "Many basic laws adopted at the time of independence were mirror texts of the constitutions in operation in the northern hemisphere and more particularly in the former colonial powers ... [S]omewhat forgotten in the 1970s and 1980s ... these [texts] were resurgent in the 1990s with the beginning of the process of democratic transition". Thus, external influences are considered to be dominant once again.

Thus, identifying the motivations behind constitutional choice in postindependence sub-Saharan Africa provides an appropriate case for examining the extent to which institutions have been chosen endogenously or exogenously. While constitutional choice is a matter for sovereign domestic actors, there are good reasons to believe that the wording of post-independence constitutions in this region may have been largely the result of direct or indirect French influence. If this were the case, then we could conclude that constitutions were chosen exogenously and, therefore, we would be well placed to determine the effect of institutions on post-independence outcomes.

\section{Research design}

This study aims to identify and explain the 'Frenchness' of post-independence Francophone sub-Saharan African constitutions in 15 countries in that region. The study covers the period from the point of independence to 2010 inclusive. 
The observations are country years. If there is a new constitution or if a constitutional change occurs part-way through a year, then it is recorded for that year only if it occurs before 1 July. Otherwise, all else equal, it is recorded for the following year. This point applies to the first observation for each country. If independence in 1960 occurred prior to 1 July, then this year is the first recorded year. Otherwise, 1961 is the first country year. The first observation for Guinea is 1959. There is a maximum of 756 observations.

The identification of constitutions, constitutional amendments, and documents with a constitutional status is always highly contestable. This study relies on the definition identified by Elkins et al. (2009, p. 49):

Constitutions consist of those documents that either: (1) are identified explicitly as the Constitution, Fundamental Law, or Basic Law of a country; OR (2) contain explicit provisions that establish the documents as the highest law, either through entrenchment or limits on future law; OR (3) define the basic pattern of authority by establishing or suspending an executive branch of government (emphasis in the original).

This definition is operationalised under the heading of the Comparative Constitutions Project (CCP).. The CCP has generated a dataset that identifies new constitutions and constitutional amendments for all of the countries and for almost of the period under consideration here. Thus, we aimed to gather the text of all of the constitutional documents identified in the CCP dataset." In addition, various constitutional documents were identified that are not recorded in the CCP dataset. These documents were included in this study." The distribution of constitutional moments with the various dates is presented in Table 1. Consistent 
with the Elkins et al. definition, the list includes new constitutions, constitutional amendments, constitutional charters, fundamental acts, suspensions, and ordinances with constitutional force. Table 1 identifies 219 constitutional moments in the 15 countries under consideration from the first year of independence until 2010 inclusive. Each of the 219 constitutional moments has the potential to change the 'Frenchness' of a country's constitution. Thus, there is always the potential for the 'Frenchness' of constitutions to vary from one country to another at any given time. Moreover, even though the number of constitutional moments varies across the set of countries, Table 1 shows that there is also the potential for considerable variation within any given country over time. It proved impossible to gather a small number of constitutional documents." Thus, there are 733 country years in the dataset here.

Table 1 about here.

The 'Frenchness' of any given constitution is measured in the following way. Eight words or very short phrases were identified that have consistently been present in the French Constitution since 1958. They are listed in Table 2. The words or phrases were chosen for four reasons. Firstly, they were only introduced into the French constitutional canon in September 1958. The 1958 constitution was very different from the previous constitution - the Constitution of the Fourth Republic. ${ }^{\text {ii }}$ The adoption of a substantively new constitution in 1958 means that if former French colonies have employed the various words or short phrases in their post-independence constitutions, then they must have done so because they are borrowing from the wording of the 1958 Constitution rather than adopting provisions that might be thought of as belonging to a common and long-standing constitutional fabric. Therefore, we have the opportunity to 
determine the extent to which the country's former colonies explicitly chose to adopt constitutional clauses that were new to the French system. Secondly, by identifying individual words or very short phrases rather than trying to identify the general powers of political actors or institutional structures, we maximise the reliability of the coding process. We do not have to make a judgment call as to whether a particular actor enjoys a certain power. Instead, we can simply identify the presence or absence of specific words or very short phrases. Thirdly, we code words or very short phrases rather than, say, presidential or legislative powers because such powers would most likely be identifiable in country constitutions generally. For example, if we coded whether or not a president enjoyed veto power, we would not be capturing the 'Frenchness' of a constitution. However, when we code the use of the specific word 'arbitrage', then we can reasonably conclude that there was a French influence on the wording of the constitutional text. Fourthly, we avoid 'common' verbs, prepositions and adjectives. Thus, we minimise the likelihood that countries could have routinely chosen the specific terms and maximise the likelihood that they have chosen a peculiarly French constitutional term. In these ways, the eight words and phrases aim to capture the relative 'Frenchness' of any given constitution. The lower the level of 'Frenchness', the greater the likelihood that a constitution was chosen endogenously. The greater the level of 'Frenchness', the greater the likelihood that the constitution was imported or imposed on the country in question.

If a constitution includes the specified word or phrase, then it is coded 1. If it does not, then it is coded 0. Therefore, there is a 9-point scale of 'Frenchness', ranging from a minimum of 0 to a maximum of 8 . It should be stressed that the 
score does not aim to capture whether countries have adopted a French-style semi-presidential constitution. ${ }^{\text {vii }}$ The chosen phrases do not relate to overarching institutional structures. Therefore, whether a country has chosen presidential, parliamentary or semi-presidential institutions, it could still generate a score between $0-8$ on the scale of 'Frenchness'. It should also be stressed again that the score does not measure the power of any particular actor. Apart from the fact that many powers are not included in the measure of 'Frenchness', a score of 1 is recorded even if a different actor from the one identified in the French constitution is associated with the particular word or phrase. For example Art. 21 of the 1958 French Constitution states that the prime minister 'dirige l'action $d u$ gouvernement' (directs the action of the government). In the measure of 'Frenchness' used here, we are interested in whether countries have used the phrase 'dirige l'action du gouvernement' rather than whether they have ascribed this power to the prime minister, the president or any other actor. If they have, then whoever the power is ascribed to a score of 1 was still recorded. Finally, a score of 1 is only recorded if the exact phrase is found in the constitution. If a similar phrase is used, then a score of 0 was recorded. For example, Art. 64 of the 1958 French constitution employs the term 'garant de l'indépendance de l'autorité judiciaire'. If a former French colony uses a similar but nonetheless different phrase such as 'garant de l'independance des juges', or 'garant de l'independance du pouvoir judiciaire', or 'garant de l'independance de la justice', then a score of 0 was recorded. Table 2 shows that there is variation in the overall frequency of the eight indicators across the set of country years. Table 3 provides the basic distribution of scores for each country, demonstrating that there is both crosscountry and within-country variation. 
Tables 2 and 3 about here

The basic aim of this study is to determine the extent to which the motivations for constitutional choice have been endogenous or exogenous. To identify exogenous preferences, we identify a set of explanatory variables that capture potential French influence. A HISTORY variable captures the length of time that a country was under direct French colonial rule (including Mandate rule). We would expect that the longer a country spent under French colonial rule, the more 'French' its constitution will be. We use various historical sources to identify the duration in years of colonial rule. This variable is time-invariant. An AID variable records the percentage of total foreign overseas aid that a country receives that comes from France. We would expect that the greater the percentage of aid from France, the more 'French' the constitution is likely to be. We take the annual figures from the OECD Development statistics. An IMPORT variable records the percentage of a country's total imports that come from France. If a country is highly dependent of French imports, then we would expect France's influence to be greater and constitutions to be more 'French'. The figures were calculated from the Barbieri et al. (2008) Correlates of War Project Trade Data Set (dyadic trade data and national - monadic - trade data). A SECURITY variable records the years when there has been a French military intervention in a country. This is a dummy variable coded 1 for an intervention year and 0 otherwise. We would expect French influence to be greater when there is a military intervention. We identify military interventions from the list in Charbonneau (2009, pp. 69-73). Finally, a PRES variable captures the personal and cultural links between France and its former colonies. We identify whether or not the head of state has spent any period of time studying in France and/or 
whether s/he was a member of the French National Assembly or the upper house (then the Council of the Republic) prior to independence in 1960. This is a dummy variable coded 1 if the head of state has been educated in France or served as a representive to French institutions and 0 otherwise. We would expect the 'Frenchness' of a constitution to be greater if the head of state has been educated in France.

To identify endogenous influences we identify a PARTY variable. We would expect that the French model is more likely to be adopted when there is more competition within the political process. When the process of constitutional choice is dominated by a single person or party, then the latitude for idiosyncratic constitutional wording is greater. The example of Bokassa's Central African Empire springs immediately to mind. However, when there is competition, then there is more likely to be compromise. In this case, parties are more likely to stick closely to the democratic model with which they are most familiar and the constitution will be more 'French' as a result. We take the level of political competition from the Cheibub, Gandhi and Vreeland Democracy and Dictatorship Revisited dataset.» This dataset includes an lparty variable, which captures party competition in the legislature and is coded 0 when there are no parties, 1 when there is one party or one de facto regime party front, and 2 where there are multiple parties. We also include a MILITARY variable. This records the years when a country was headed by a military leader. We would expect military leaders to suspend the full constitution and to rule by decree on the basis of a constitutional ordinance. Thus, when there is a military leader, the level of 'Frenchness' should be low. This is a dummy variable coded 1 in a year when there is a military leader and 0 otherwise. The identification of military 
leaders is taken from the worldstatesmen.org website.* The POP variable records the natural log of a country's population. There is no explicit expectation associated with this variable. A country with a small population might be more susceptible to French influence. Equally, a country with a large population might be more strategically important to France and, therefore, may be the object of greater French attention. We take the population statistics from the World Bank's World Development Indicators. Finally, a GDP variable records the natural log of a country's GDP per capita. Again, there is no explicit expectation associated with this variable. A country with a low GDP per capita might be more open to French influence. Equally, a country with a high GDP might be a more important partner for France. We take the GDP per capita figures from the World Bank's World Development Indicators.

In addition, we include two time controls. Given the French constitutional model was said to be adopted more systematically in the early years of independence and in the period following the end of the Cold War, we include two dummy variables, a 1960 variable coded 1 for the period up to 1969 inclusive and 0 afterwards and a 1990 variable coded 1 for all years from 1991 inclusive onwards and 0 beforehand. We expect the degree of 'Frenchness' to be greater in these periods than otherwise.

The research design generates time-series cross-sectional data. We have data for 15 separate countries. We employ three estimation techniques. Model 1 uses panel-corrected standard errors (PCSE) with the Prais-Winsten transformation (Beck and Katz, 1995). This model is an appropriate way of accounting for contemporaneously correlated panels. In this model the dependent variable is a continuous variable. Model 2 is an ordered probit 
regression with country-clustered standard errors. In this model the dependent variable is an ordinal variable that can, in theory, range from 0-8. However, no country records a score of 8 . Moreover, only Benin and Senegal record a score of 7 and then for only two years each (1964 and 1965, and 1961 and 1962 respectively). Therefore, we omit these two observations from Model 2. Otherwise, Table 4 shows that the distribution of the dependent variable is relatively even. Model 3 is a pooled model with country fixed-effects. Here, the dependent variable is continuous. The Hausman test indicates that this model should be used rather than a random effects model. In Model 3 the HISTORY variable is dropped because it is time-invariant for each country and, therefore, would be perfectly collinear with the fixed effect for that country.

Table 4 about here

\section{Results and interpretation}

The results of the estimations are presented in Table 5. The findings are very consistent across the three models. They confirm that the motivations for constitutional choice have been both endogenous and exogenous. For the set of exogenous factors, four variables (AID, HISTORY, IMPORT, and SECURITY) were significant at conventional levels in all three models. However, three of these variables (AID, HISTORY, and IMPORT) returned tiny coefficients and the finding for the HISTORY variable was in the opposite direction to the one that was hypothesised. By contrast, the SECURITY variable had a relatively large coefficient and was in the expected direction. In addition, the PRES variable was highly significant in Model 1 and was in the expected direction with a large 
coefficient. Even so, it was not significant in the other two models. For the set of endogenous factors, the results were somewhat stronger. In all three Models, two variables (PARTY, and MILITARY) were highly significant at conventional levels. Moreover, they had relatively large coefficients and were in the hypothesised direction. Another variable (POP) returned inconsistent results. It was significant in all three models, but there was a positive relationship between population and 'Frenchness' in two models and a negative relationship in the third model. The GDP variable was not significant in any model. In terms of the control variables, there was strong support for the 1990 variable. This variable was significant, with a large coefficient and in the expected direction in all three models. There was somewhat less support for the 1960 variable, which produced a similar result in only two of the three models.

Table 5 about here

Various robustness tests were carried out, but are not reported. In place of Model 2, an ordered logistic regression was estimated. The results were substantively the same as those presented in Table 5. A dummy variable for Guinea was also included in Models 1 and 2. Guinea is somewhat unusual within the set of former French colonies in sub-Saharan Africa. It was the only country to reject the French Community in 1958 and to vote for independence and was spurned by France because of this choice. For its part, Guinea attempted to forge an independent set of policies. Overall, we would expect Guinea to have a low level of 'Frenchness' in its constitutional choices. This expectation was strongly supported when Guinea was included in the equation, but the substantive results for the other variables were unchanged. An additional indicator of 'Frenchness' was also included to ensure that the results were not 
sensitive to the specific choice of indicators. Thus, the presence or absence of the term 'indivisibilité' in each country's constitutions was coded. The results using the subsequent 10-point scale were substantively the same as those reported using the 8-point scale. VIF tests also showed that there is no problem of collinearity among the explanatory variables. The highest VIF figure was 2.45 and the lowest Tolerance figure was 0.41 .

These results are highly suggestive. They demonstrate that constitutional choice was a mix of both endogenous and exogenous motivations. This result is interesting because the standard wisdom suggests that external French influence has been extremely strong in this region since 1960, implying that institutional choice was likely to be mainly exogenous. Certainly, there is evidence that French military interventions have had an effect on constitutional wording. Presumably, military interventions, whether requested or imposed, have been accompanied by the presence of non-military advisers, who have had a direct influence on constitutional wording. There is also some support for the idea that political leaders with a French education are associated with constitutions that are more 'French' than those that have been educated purely locally. All the same, the impact of endogenous factors is greater than the standard wisdom would suggest. Most notably, there is unequivocal support for the idea that party competition has increased the 'Frenchness' of constitutions, presumably by reducing the opportunity for idiosyncratic decision-making and by encouraging consensus around constitutional focal points that correspond to the French constitution. In short, while there is evidence to suggest that the wording of postindependence constitutions in this region has been influenced directly or indirectly by French influence, there is also evidence to support the claim that 
post-independence Francophone sub-Saharan African countries have managed their own constitutional destinies. They may have done so within a general framework of French constitutional law, but they have been willing and able to make specific choices that diverge from the precise form of the French model. In this event, the standard narrative of overweening French influence since 1960 needs to be reinterpreted.

The finding that constitutional choice has been a mix of both endogenous and exogenous motivations is consistent with the idea that post-independence decision-makers considered themselves to be both French and African, generating personalities with a mix of both 'domestic' and 'external' preferences. This idea fits the first generation of post-independence leaders very well. For example, the first president of Senegal, Léopold Sédar Senghor, was a proponent of the concept of 'negritude', which he defined as "the sum total of the qualities possessed by all black men everywhere" (Vaillant, 1990, p. 244), generating a very specific life experience. At the same time, Senghor was a former member of the French National Assembly, a State Secretary in the French government from 1955-56, and later a member of Académie française, implying an enduringly close relationship with French language, life, and culture. In his work on the end of empire, Tony Chafer (2002b, p. 16) has argued that such leaders "saw themselves as simultaneously African nationalists and part of a wider French community". To date, such an interpretation has been based on purely qualitative narratives. The findings in this article suggest that other research methods might also be used to advance such a claim.

Overall, we must acknowledge that we have only tested for the impact of exogenous French influence. In the 1970s it is clear that certain countries were 
inspired by Soviet-style single-party constitutions. Moreover, since the beginning of the 1990s countries have, arguably, been shaped by a more diverse set of constitutional influences than merely the French model (Bourgi, 2002, p. 723). Generally, though, by estimating the motivations for constitutional choice directly we are well placed to proceed to a more informed study of the causal effect of institutions in this region. The results of the first-stage estimation presented above suggests that exogenous motivations were associated with institutional choice. Therefore, it is reasonable to believe that institutions may have had at least some independent causal impact. The precise nature of any such impact could now be investigated in the second-stage of a study of postindependence institutions in this region. At the same time, the results also showed that there have been endogenous influences. The second-stage of such a study could now focus directly on the impact of the specific endogenous variables that were identified. For example, what is the process by which increased party competition has generated constitutions that are more 'French'? The second stage of the research project may still need to employ instrumental variables, natural experiments and equivalent research strategies, but this stage would be more able to proceed in a more focused way because of the first-stage estimation.

\section{Conclusion}

We assume that institutions shape political preferences and have a causal effect on political outcomes. However, institutions generally, and constitutions among them, are necessarily preference-induced. If institutions are chosen purely 
endogenously, then we would have to question the extent to which they have any independent causal effect. This article has proposed a strategy for addressing the issue of endogenous institutional choice. As the first part of a two-stage strategy to address the endogeneity problem, this article has directly estimated the motivations behind constitutional choice in post-independence Francophone sub-Saharan Africa. We find that they were a mix of endogenous and exogenous preferences. The finding that constitutional choice was at least partly exogenous suggests that we have reason to believe post-independence institutions have had at least some causal influence. This result acts as the equivalent of a first-stage robustness test for a study of institutions in this region. The finding that constitutional choice was also at least partly endogenous suggests that we have to take into specific domestic preferences when estimating the independent effect of institutions. By identifying particular endogenous influences, we are well placed to take account of these motivations in the second stage of a study of institutions in this region. By doing so, we will be able to make more reliable recommendations about the effects of institutions on political outcomes. 
Notes

i All translation from the French are by the author.

ii All translation from the French are by the author.

iii See http://www.comparativeconstitutionsproject.org/, accessed 25 January 2011.

iv The constitutional documents were gathered from a wide variety of sources, including the Journal officiel (online and paper copy) of the various countries, online sources such as Constitutions du Monde (http://mjp.univ-perp.fr/ accessed 25 January, 2011), general sources such as Reyntjens, (1988), journal sources such as Année africaine (various years), Revue Juridique et Politique d'Outremer (various years), and Revue Politique et Juridique (Indépendance et Cooperation) (various years), as well as country-specific sources such as Fall (2007) and Reynal (1994). The CCP dataset ends in 2006. Therefore, amendments from 2007-2010 inclusive were identified by the author.

v The additional texts are Cameroon (1983, 1988 and 1991 amendments), Central African Republic (1991 and 1992 amendments), Congo (1997 document), Côte d'Ivoire (1986 and 1995 amendments), Gabon (1966, 1969, 1972, 1979, 1983, 1986, 1990, 1995 and 2000 amendments), Guinea (1996 and 2002 amendments), Madagascar (1971, 1988, 1989 amendments), Mali (1969 and 1982 amendments and the 1991 document), Mauritania (1979, 1981 and 2005 document), Niger (2004 amendment), Senegal (1961, 1999, 2003 and 2006 amendments) and Togo (1966, 1988 and 2005 amendments). In addition, the CCP dataset records a new constitution in Benin in 1979, whereas the constitution was adopted in August/September 1977. Also, the CCP dataset records an amendment in Mauritania in 1971. There were two amendments in 1970, but none has been identified in 1971. Finally, in a small number of cases there is more than one constitutional document in the year. If each lasts for more than six months, then both are recorded. For example, in the Central African Republic the February 1981 constitution is recorded for 1981, whereas the September 1981 documents are recorded for 1982 onwards. In the CCP dataset, the Central African Republic 1981 is simply recorded as an "event", rather than two events.

vi The following documents and subsequent country years are missing: Benin (Dec. 1965 - 1966 and 1967); Cameroon Apr. 1991 - 1991-1995 inclusive); Central 
African Republic (Sep. 1985 - 1986); Chad (Apr. 1995 - 1995); Congo (1990 1990); Guinea (Apr. 1984 - 1984-1990 inclusive); and Mali (1985 - 1985-1990 inclusive).

vii The text of the 1946 Constitution is available at: http://mjp.univperp.fr / france/ co1946-0.htm, accessed 18 March 2011.

viii It should be noted, of course, that France only became semi-presidential in 1962.

ix The data set is available at:

https://netfiles.uiuc.edu/cheibub/www/DD_page.html, accessed 25 January 2011.

x See http:/ / www.worldstatesmen.org, accessed 25 January 2011. 
Table 1 Constitutional moments in 15 Francophone sub-Saharan African countries from independence to 2010 inclusive

Country

Benin

Burkina Faso

Cameroon

Central African

Republic

Chad

Congo-Brazzaville

\author{
Total
}

12 Nov. 1960; Jan. 1964; Dec. 1965; Mar. 1968; May 1970; Oct. 1972; Nov. 1972; Apr. 1973; May 1973;

Aug. 1977; Mar. 1984; Aug. 1990

13 Nov. 1960; Jan. 1963; Jan. 1966; Jun. 1970; Feb. 1974; Dec. 1977; Nov. 1980; Aug. 1983; Mar. 1988;

Jun. 1991; Jan. 1997; Apr. 2000; Jan. 2002

14 Mar. 1960; Sep. 1961; Nov. 1969; May 1972; May

1975; Jun. 1979; Jul. 1983; Nov. 1983; Feb. 1984;

Mar. 1988; Apr. 1991; Dec. 1991; Jan. 1996; Apr. 2008

19 Nov. 1960; Apr. 1961; Dec. 1962; Nov. 1963; Nov. 1964; Jan. 1966; Dec. 1976; Sep. 1979; Feb. 1981; Sep. 1981; Sep. 1985; Nov. 1986; Mar. 1991; Jul. 1991; Aug. 1992; Dec. 1994; Mar. 2003; Dec. 2004; May 2010

14 Nov. 1960; Apr. 1962; Nov. 1965; Jul. 1967; Jun. 1975; Aug. 1978; Aug. 1979; Sep. 1982; Dec. 1989; Feb. 1991; Apr. 1993; Apr. 1995; Apr. 1996; Jun. 2005

14 Mar. 1961; Dec. 1963; Aug. 1968; Dec. 1969; Jun. 
1973; Apr. 1977; Jul. 1979; Dec. 1984; 1989; 1990;

May 1991; Mar. 1992; Oct. 1997; Jan. 2002;

Côte d'Ivoire

14 Nov. 1960; Jan. 1963; May 1975; Oct. 1975; Sep.

1980; Oct. 1985; Jan. 1986; Nov. 1990; Aug. 1994;

Jun. 1995; Jul. 1998; Dec. 1999; Jul. 2000; Dec.

2004

Gabon

19 Feb. 1961; Jun. 1966; Dec. 1967; May 1968; Nov.

1968; Dec. 1969; Jul. 1972; Apr. 1975; Apr. 1979;

Aug. 1981; Mar. 1983; Sep. 1986; May 1990; Mar. 1991; Mar. 1994; Sep. 1995; Apr. 1997; Oct. 2000;

Aug. 2003

Guinea

$8 \quad$ Nov. 1958; Oct. 1963; May 1982; Apr. 1984; Dec.

1990; Oct. 1996; May 2002; Apr. 2009

Madagascar

14 Apr. 1959; Jun. 1960; Jun. 1962; Dec. 1970;

Nov. 1971; Nov. 1972; Dec. 1975; Dec. 1988; Dec. 1989; Aug. 1992; Oct. 1995; Apr. 1998; Apr. 2007;

Mar. 2009

Mali

13 Jun. 1960; Sep. 1960; Jan. 1961; Nov. 1968; Aug. 1969; Jun. 1974; May 1979; Sep. 1981; Apr. 1982; 1985; 1988; Mar. 1991; Feb. 1992

Mauritania

19 May 1961; Apr. 1964; Feb. 1965; Jul. 1966; Mar. 1968; Jan. 1969; Apr. 1970; Jun. 1970; Jul. 1978; Apr. 1979; Jan. 1980; Dec. 1980; Apr. 1981; Feb. 1985; Jul. 1991; Aug. 2005; Jul. 2006; Aug. 2008; 
Jul. 2009

Niger

Senegal

Togo

Total
13 Nov. 1960; Aug. 1964; Sep. 1965; Apr. 1974; Jan. 1983; Sep. 1989; Apr. 1991; Dec. 1992; May 1996;

Jul. 1999; May 2004; Jul. 2009; Feb. 2010

31 Aug. 1960; Nov. 1961; Dec. 1962; Mar. 1963; Jun. 1967; Mar. 1968; Feb. 1970; Mar. 1976; Apr. 1976; Dec. 1978; May 1981; May 1983; May 1984; Feb. 1991; Apr. 1991; Oct. 1991; Jan. 1992; May 1992; Jun. 1994; Mar. 1998; Oct. 1998; Jan. 1999; Jan. 2001; Jun. 2003; Jan. 2006; Nov. 2006; Feb. 2007; May 2007; Aug. 2008; Oct. 2008; Jun. 2009 12 Apr. 1960; Apr. 1961; Jan. 1963; May 1963; Dec. 1966; Jan. 1967; Dec. 1979; May 1988; Oct. 1992; Dec. 2002; Feb. 2005; Feb. 2007 
Table 2 Eight indicators of the 'Frenchness' of Francophone sub-Saharan African constitutions and the total number of times they were identified (max. 733)

Article in 1958

Text (word or phrase in italics)

Total

French Constitution

Art. 4

... concourent a`l'expression du suffrage...

Art. 5

... arbitrage...

144

Art. 16

... sont menacées d'une manière grave et immédiate

Art. 20

... détermine et conduit ...

Art. 21

... dirige l'action ...

Art. 40

... soit une diminution des ressources publiques,

464 soit la création ou l'aggravation d'une charge publique

Art. 52

... négocie et ratifie ...

407

Art. 64

... garant de l'indépendance de l'autorité judiciaire

91

Legend: word/phrase is in bold italics

Source:

http:/ / www.conseil-constitutionnel.fr/ conseilconstitutionnel/root/bank_mm/constitution/constitution.pdf Accessed 25 January 2011 
Table 3 Descriptive statistics for the 'Frenchness' of constitutions in 15 Francophone sub-Saharan African countries from independence to 2010 inclusive

$\begin{array}{lcccc}\text { Country (start year) } & \begin{array}{c}\text { Highest } \\ (\max 8)\end{array} & \text { Lowest } & \text { Average } & \begin{array}{c}\text { Standard } \\ \text { deviation }\end{array} \\ \text { Benin (1961) } & 7 & 0 & 3.02 & 2.51 \\ \text { Burkina Faso (1961) } & 6 & 0 & 3.26 & 2.48 \\ \text { Cameroon (1960) } & 6 & 2 & 4.26 & 1.48 \\ \text { Central Af. Rep. (1961) } & 5 & 1 & 2.63 & 1.55 \\ \text { Chad (1961) } & 6 & 0 & 4.00 & 2.11 \\ \text { Congo-Brazzaville (1961) } & 6 & 0 & 2.10 & 1.92 \\ \text { Côte d'Ivoire (1961) } & 5 & 1 & 4.92 & 0.57 \\ \text { Gabon (1961) } & 6 & 2 & 3.94 & 1.75 \\ \text { Guinea (1959) } & 3 & 1 & 1.89 & 1.01 \\ \text { Madagascar (1960) } & 5 & 0 & 3.16 & 1.27 \\ \text { Mali (1960) } & 5 & 1 & 3.60 & 1.36 \\ \text { Mauritania (1961) } & 5 & 0 & 2.26 & 2.15 \\ \text { Niger (1961) } & 6 & 0 & 3.70 & 2.46 \\ \text { Senegal (1961) } & 7 & 3 & 3.30 & 0.84 \\ \text { Togo (1960) } & 6 & 0 & 2.86 & 1.87\end{array}$


Table 4 The distribution of the dependent variable

$\begin{array}{ccc}\text { Score } & \text { Frequency } & \text { Percentage } \\ 0 & 90 & 12.28 \\ 1 & 91 & 12.41 \\ 2 & 61 & 8.32 \\ 3 & 146 & 19.92 \\ 4 & 73 & 9.96 \\ 5 & 189 & 25.78 \\ 6 & 79 & 10.78 \\ 7 & 4 & 0.55 \\ 8 & 0 & 0.00\end{array}$


Table 5 Factors affecting constitutional choice in 15 Francophone subSaharan African countries

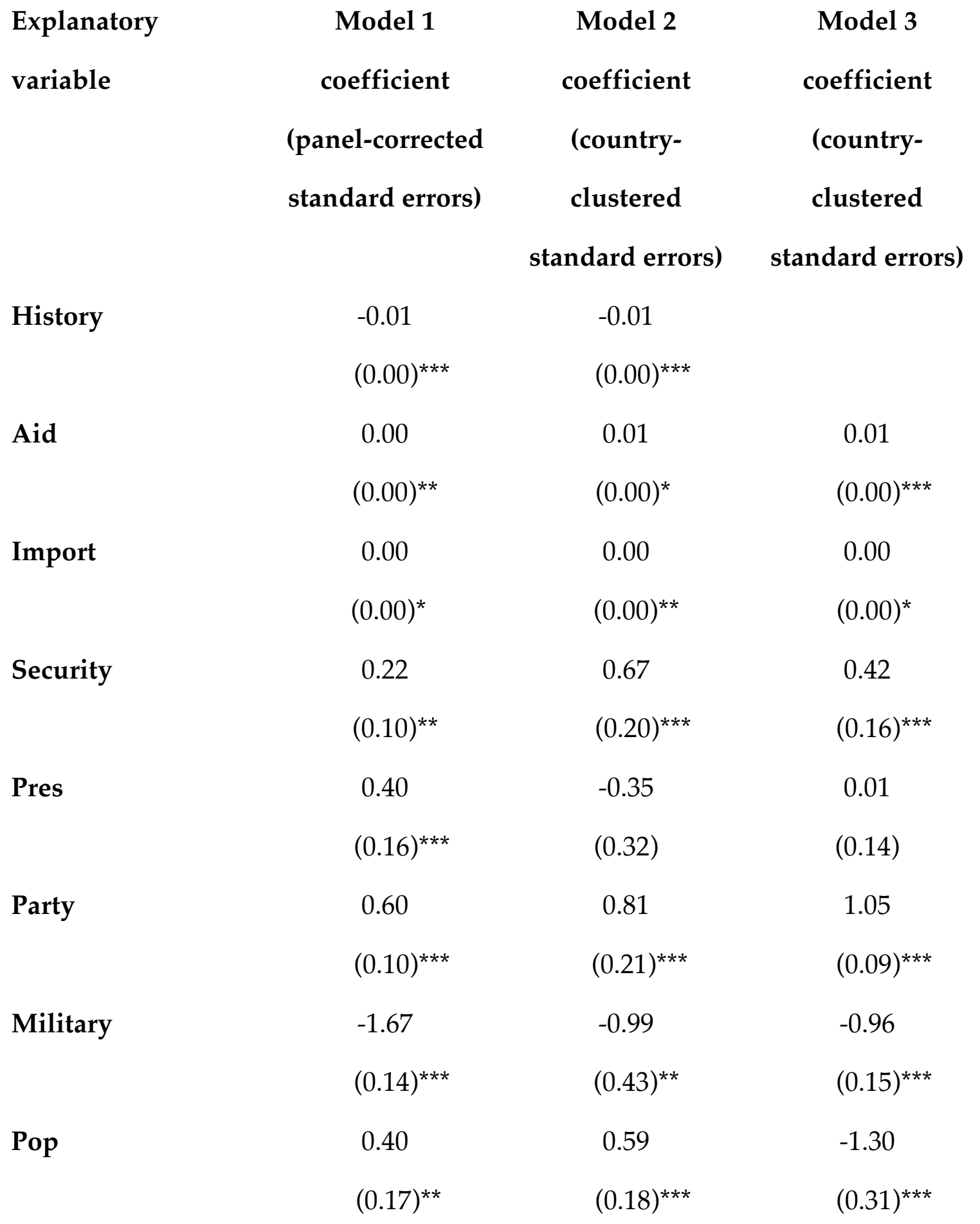




$\begin{array}{lccc}\text { GDP } & 0.23 & 0.31 & 0.11 \\ & (0.18) & (0.27) & (0.26) \\ \mathbf{1 9 6 0} & 0.38 & 0.69 & 0.20 \\ & (0.17)^{* *} & (0.33)^{* *} & (0.18) \\ \mathbf{1 9 9 0} & 0.97 & 0.58 & 1.74 \\ & (0.17)^{* * *} & (0.36) & (0.21)^{* * *} \\ \text { Constant } & -2.09 & & 11.32 \\ & (2.33) & & (3.27)^{* * *} \\ \text { N= } & & & \\ \text { No. of } & 618 & 616 & 618 \\ \text { panels/countries } & 15 & 15 & 15 \\ \mathbf{R}^{2} & & & \\ \text { Wald Chi } & 49.4 & 24.0 & 26.0 \\ & 443.41 & 494.72 & \end{array}$

${ }^{*}$ significant at $\mathrm{p}<0.1,{ }^{* *}$ significant at $\mathrm{p}<0.05,{ }^{* * *}$ significant at $\mathrm{p}<0.01$ 


\section{References}

Ager, D. E. (2005), 'French Cultural, Languages and Telecommunications Policy Towards Sub-Saharan Africa', Modern and Contemporary France, 13:1, 57-69.

Aghion, Philippe, Alberto Alesina, and Francesco Trebbi (2004), "Endogenous Political Institutions", Quarterly Journal of Economics, 119:2, 565-611.

Alesina, Alberto, Arnaud Devleeschauwer, William Easterley, Sergio Kurlat and Roman Wacziarg (2003), "Fractionalization", Journal of Economic Growth, 8, 155-194.

Ayissi, Anatole N. (1999), ‘Powershift and Strategic Adjustment in French Military Engagement in Central Africa', African Journal of Political Science, $4: 2,16-45$.

Beck, Nathaniel, and Jonathan N. Katz (1995), “What To Do (And Not To Do) With Time-Series Cross-Section Data", American Political Science Review, $89: 3,634-647$.

Bourgi, Albert (2002), “L'évolution du constitutionnalisme en Afrique: du formalisme à l'effectivité", Revue française du Droit constitutionnel, 52, 721748.

Cabanis, André, and Michel Louis Martin (2005), “Un espace d'isomorphisme constitutionnel", in La Constitution et les valeurs. Mélanges en l'honneur de Dmitri Georges Lavroff, Paris: Dalloz, pp. 343-358.

Chafer, Tony (2002a), 'Franco-African relations: no longer so exceptional?', African Affairs, 101, 343-363.

Chafer, Tony (2002b), The End of Empire in French West Africa. France's Successful Decolonisation, Oxford: Berg. 
Charbonneau, Bruno (2008), 'Dreams of Empire: France, Europe, and the New Interventionism in Africa', Modern and Contemporary France, 16:3, 279-295. Charbonneau, Bruno (2009), France and the New Imperialism: Security Policy in subSaharan Africa, Aldershot: Ashgate.

Collier, David, Henry E. Brady, and Jason Seawright (2004), “Sources of Leverage in Causal Inference: Toward an Alternative View of Methodology", in Henry E. Brady and David Collier (eds.), Rethinking Social Inquiry: Diverse Tools, Shared Standards, Lanham, MD: Rowman \& Littlefield, pp. 229-266.

Conac, Gérard (1979), “L'évolution constitutionnelle des États francophones d'Afrique noire et de la République démocratique malgache", in Gérard Conac (ed.), Les institutions constitutionnelles des États d'Afrique francophones et de la République malgache, Paris: Economica, pp. 1-68.

Davies, H. O. (1963), "The Legal and Constitutional Problems of Independence", in Peter Judd (ed.), African Independence. The Exploding Emergence of the New African Nations, New York: Dell Publishing Co., pp. 328-353.

du Bois de Gaudusson, Jean (2009), "Le mimétisme postcolonial, et après?", Pouvoirs, 129, 45-55.

Elkins, Zachary A., Tom Ginsburg, and James Melton (2009), The Endurance of National Constitutions, Cambridge: Cambridge University Press.

Engerman, Stanley L., and Kenneth L. Solokoff (2008), “Debating the Role of Institutions in Political and Economic Development: Theory, History, and Findings", Annual Review of Political Science, 11, 119-135.

Fall, Ibrahima (1971), “La réforme constitutionnelle du 22 février 1970 au Sénégal", Penant, 731, 91-114. 
Fall, Ismaila Madior (2007), Textes constitutionnels du Sénégal de 1959 à 2007, Dakar: CREDILA.

Gerber, Alan S., and Donald P. Greene (2008), “Field Experiments and Natural Experiments", in Janet M. Box-Steffensmeier, Henry E. Brady, and David Collier (eds.), The Oxford Handbook of Political Methodology, Oxford: Oxford University Press, pp. 357-382.

Glélé, Maurice-Ahanhanzo (1980), “Le modèle constitutionnel français et son influence sur les États africains liés à la France", in La politique africaine du Général de Gaulle (1958-1969), Paris: Éditions A. Pédone, pp. 31-52.

Golan, Tamar (1981), 'A certain mystery: How can France do everything that it does in Africa - and get away with it?', African Affairs, 80, 3-11.

Goncharov, L. (1963), 'New forms of colonialism in Africa', Journal of Modern African Studies, 1:4, 467-474.

Gregory, Shaun (2000), 'The French military in Africa: past and present', African Affairs, 99, 435-448.

Hugon, Philippe (2005), ‘Permanences et ruptures de la politique économique de la France vis-à-vis de l'Afrique sub-Saharienne', Modern and Contemporary France, 13:1, 41-55.

Joseph, Richard (1976), 'The Gaullist legacy: Patterns of French Neo-colonialism', Review of African Political Economy, 6, 4-13.

Le Vine, Victor (1997), "The Fall and Rise of Constitutionalism in West Africa", Journal of Modern African Studies, 35:2, 181-206.

Luckham, Robin (1982), 'French Militarism in Africa', Review of African Political Economy, 24, 55-84. 
Majumdar, Margaret A., and Tony Chafer (2010), Back to the Future? FrancoAfrican Relations in the Shadow of France's Colonial Past, in Tony Chafer and Emmanuel Godin (eds.), The End of the French Exception? Decline and Renewal of the 'French Model', London: Palgrave, pp. 203-220.

Mbaku, John Mukum (2003), “Constitutionalism and the Transition to Democratic Governance in Africa", in John Mukum Mbaku and Julius Omozuanvbo Ihonvbere (eds.), The Transition to Democratic Governance in Africa. The Continuing Struggle, Westport CN: Praeger, pp. 103-135.

Murray, Michael P. (2006), "Avoiding Invalid Instruments and Coping with Weak Instruments", Journal of Economic Perspectives, 20:4, 111-132.

Petiteville, Franck (1996), “Quatre décennies de 'coopération franco-africaine': usages et usure d'un clientelisme", Revue Études internationales, 27:3, 571601.

Plümper, Thomas, and Vera A. Troeger (2007), “Efficient Estimation of TimeInvariant and Rarely Changing Variables in Finite Sample Panel Analyses with Unit Fixed Effects", Political Analysis, 15, 124-139.

Przeworski, Adam (2004), "Institutions matter?", Government and Opposition, 39:4, $527-540$.

Renou, Xavier (2002), 'A New French Policy for Africa?', Journal of Contemporary African Studies, 20:1, 5-23.

Reynal, Jean-Jacques (1994), Les institutions politiques du Niger, Paris: Sépia. Reyntjens, Filip (1988) Constitutiones Africae, Brussels: Bruylant.

Reyntjens, Filip (1991), “The Winds of Change. Political and Constitutional Evolution in Francophone Africa, 1990-1991", Journal of African Law, 35, 4455. 
Shvetsova, Olga (2003), “Endogenous Selection of Institutions and Their Exogenous Effects", Constitutional Political Economy, 14, 191-212.

Sovey, Allison J., and Donald P. Green (2011), “Instrumental Variables Estimation in Political Science: A Readers' Guide", American Journal of Political Science, 55:1, 188-200.

Suret-Canale, Jean (1974), ‘Difficultés du néo-colonialisme français en Afrique tropicale', Canadian Journal of African Studies, 8:2, 211-233.

Ticchi, Davide, and Andrea Vindigni (2010), “Endogenous Constitutions”, The Economic Journal, 120, 1-39.

Vaillant, Janet (1990), Black, French, and African: A Life of Léopold Sédar Senghor, Cambridge MA: Harvard University Press.

Verschave, François-Xavier (1998), La Françafrique. Le plus long scandale de la République, Paris: Stock.

Verschave, François-Xavier (2000), Noir silence. Qui arrêtera la Françafrique?, Paris: Les Arènes. 